\title{
6 From Slave Purchases to Child Redemption: A Comparison of Aristocratic and Middle-Class Recruiting Practices for "Exotic" Staff in Habsburg Austria
}

Dark-skinned domestics are well-known to us as a characteristic element of aristocratic representation in early modern times. They served at the courts of kings and princes, archbishops and abbesses, leaving traces in art and literature as well as in certain customs and traditions. Their presence outlasted the Baroque period, however. We encounter them again in the households of the upper class during the nineteenth century, sometimes even later - despite the abolition of slavery and the slave trade in Europe, despite the societal changes brought about by the industrial revolution, and despite the fact that the structure of the public was changing fundamentally. The desire among the elites to exoticize their public as well as private lives by instrumentalizing persons from overseas had become a cross-epochal constant. At the same time, however, the political and legal framework conditions for recruiting ${ }^{1}$ and employing Black domestic servants had changed fundamentally, so that we must ask about the underlying structures allowing the practice to be maintained. The following text, which is embedded in a larger research project on slave trading and slavery in Austrian history, therefore explores - using a comparative approach - the changes in the function of "exotic servants" and the practices for procuring them during and after the era of the transatlantic respectively trans-Mediterranean slave trade, i.e. between the sixteenth and eighteenth centuries on the one hand and during the nineteenth century on the other.

\section{"Exotic" Domestics and Feudal Representation}

The Prince [. . .] traveled in a magnificent gala carriage drawn by six black horses, in a goldembroidered coatdress and hat with white imperial feathers. The stablemaster rode ahead of the carriage, accompanied by grooms leading six horses with richly embroidered blankets. They were followed by the princely court forager Bauer on a horse, accompanied by two porters, six

1 Technical collective terms like "procuring" or "recruiting" are intentionally used to subsume the various different practices that will be mentioned in this text. This phrasing is not intended to trivialize the fact that many of these practices were violent and inhumane.

Translation: Stephan Stockinger

Ә Open Access. ( 2021 Walter Sauer, published by De Gruyter. (c) BY-NC-ND This work is licensed under the Creative Commons Attribution-NonCommercial-NoDerivatives 4.0 International License.

https://doi.org/10.1515/9783110748833-007 
messengers, 46 servants, six hussars, and two rifle loaders, all wearing magnificent gala liveries. Behind the Prince's parade carriage followed the 'high-princely chamber Moor (Hochfürstliche Cammer-Mohr) and six high-princely pageboys in rich gala livery, with white silk stockings, on horses. $^{2}$

These words, taken in part directly from an archival source and in part paraphrasing it, were used by Gerald Schlag to describe the arrival of Prince Nikolaus Esterházy I (which incidentally was also observed by Goethe) at the coronation of Emperor Joseph II in Frankfurt in 1764. Among Nikolaus's entourage was a Black servant named Jean Sibas. Similar reports on Baroque acts of state during which courtiers of African or other overseas origin were positioned prominently are not uncommon. Debrunner and others even consider the display of prestige to have been the main function of members of the African diaspora in early modern (Central) Europe. ${ }^{3}$ Indeed, it seems clear that Black individuals played an important role in the "representative publicity" of feudalism geared toward an apotheosis of the involved nobles or rulers. ${ }^{4}$ It is likewise true that - in contrast to slaves in the Americas or Turkish prisoners of war in Southern and Eastern Europe - they were generally not forced into heavy manual labor. Their affiliation with feudal courts was based on a symbolic rather than material value, namely on their physical constitution that was construed as intrinsically "different."

Although correct in principle, Debrunner's theory requires a more detailed definition in two regards. Firstly, it would be wrong to reduce the African diaspora in Europe to the so-called Hofmohren ("court Moors," the official Austrian terminology during the eighteenth century), i.e. to persons who had been lucky enough to wind up in highranking (generally noble) social environments - for this certainly did not apply to all individuals of African origin. Biographically oriented studies including those by Debrunner himself reveal a much broader spectrum of social embedding (or lack of embedding) of Black people. Secondly, even the Hofmohren themselves were reserved not only for representative purposes - as Debrunner likewise points out - but engaged in regular work as messengers, horse grooms, valets or chambermaids, trumpeters, soldiers, and so on. They were thus also economically embedded, but this integration occurred in a more exclusive segment of the service industry rather than in production and was also overlaid by their "exotic” appearance.

2 Gerald Schlag, ““. . . Die Anstalt des Fürsten Esterházy jedoch übertraf alle die übrigen.' Fürst Nikolaus I. Esterházy als kurböhmischer Wahlbotschafter bei der Wahl und Krönung Josephs II. zum römischen König 1764," in Archivar und Bibliothekar: Bausteine zur Landeskunde des burgenländischenwestungarischen Raumes. Festschrift für Johann Seedoch zum 60. Geburtstag, ed. Felix Tobler and Norbert Frank (Eisenstadt: Amt d. Burgenländ. Landesregierung, 1999), 441, 446-447.

3 Hans Werner Debrunner, Presence and Prestige: A History of Africans in Europe before 1918 (Basel: Basler Afrika-Bibliographien, 1979), 91-92.

4 Jürgen Habermas, Strukturwandel der Öffentlichkeit: Untersuchungen zu einer Kategorie der bürgerlichen Gesellschaft, 4th ed. (Neuwied: Luchterhand, 1969), 14-24.

5 This was also generally linked to notions of cultural and/or intellectual "otherness," cf. Sarah Reimann, Die Entstehung des wissenschaftlichen Rassismus im 18. Jahrhundert (Stuttgart: Steiner, 2017). 
Where did these individuals come from, what was the personal legal status they existed in, and how was their "representative" function constructed?

\section{Recruiting for Feudal Representation in the Fifteenth to Eighteenth Centuries}

Several years ago, I attempted together with Andrea Wiesböck to analyze individual pieces of information from various sources in a systematic fashion and summarize them into a "collective biography" of the African - or more precisely: Black - men and women verifiably living in Vienna during the seventeenth and eighteenth centuries. In the meantime, this study initially limited to Vienna has been supplemented with data for other Austrian provinces (and is still a work in progress). ${ }^{6}$ It has shown that employment as domestics was definitely the largest but by no means the only area of activity for the known Black diaspora between the sixteenth and eighteenth centuries. For aside from children and those grownups on whom no detailed information has been found, we encounter "paupers" not associated with a household and living on some form of welfare (for example Anton Dorres +1730$),{ }^{7}$ an inmate (Karl Magnus +1784$),{ }^{8}$ and the occasional self-employed person (like Johann Baptist Somoß, who worked as an unlicensed tailor, $\dagger$ after 1748). ${ }^{9}$ Transitions between social statuses also seem to have been more frequent than initially assumed: Some of the individuals described as "elderly" at the time of their archival mention may previously have worked as domestics, while two persons combined a position at court with a trade or craft (Emanuel Soesa $+1698,{ }^{10}$ Anton Monteur +1721$)^{11}$ and one was even able to transition into a middle-class existence - at least for a certain period of time (Angelo Soliman + 1796). ${ }^{12}$

6 Walter Sauer and Andrea Wiesböck, "Sklaven, Freie, Fremde. Wiener 'Mohren' des 17. und 18. Jahrhunderts," in Von Soliman zu Omofuma: Geschichte der afrikanischen Diaspora in Österreich 17. bis 20. Jahrhundert, ed. Walter Sauer (Innsbruck: Studienverlag, 2007), 23-56; Walter Sauer, “'Und man siehet die im Lichte, die im Dunkeln sieht man nicht.' Neue Beiträge zu einer Kollektivbiographie von Afrikanern und Afrikanerinnen im frühneuzeitlichen Österreich," Wissenschaftliches Jahrbuch der Tiroler Landesmuseen 9 (2016): 232-247.

7 Sauer and Wiesböck, "Sklaven, Freie, Fremde," 30.

8 Sauer and Wiesböck, "Sklaven, Freie, Fremde," 34.

9 Sauer and Wiesböck, "Sklaven, Freie, Fremde," 30-31.

10 Sauer, "Neue Beiträge," 241-242.

11 Sauer, "Neue Beiträge," 240-243.

12 The fact that Soliman was the best-known African in Habsburg Austria and his story has frequently been told in literature, theater, and films warrants a bibliographic reference: Philipp Blom and Wolfgang Kos, eds., Angelo Soliman: Ein Afrikaner in Wien (Vienna: Wien Museum, 2011). 
How did these persons enter the Habsburg sphere of influence? There were evidently multiple different recruiting scenarios, which interestingly also seem to have caused the respective individuals to become embedded in different social or regional milieus. In the following, I will attempt to characterize the ideal types of these scenarios:

\section{Prisoners of War from the Ottoman Wars}

A relatively small but distinct group of persons was most likely connected to the Ottoman-Habsburg wars, an ongoing conflict that escalated repeatedly beginning in the fifteenth century and reached its culmination in the advance of High Porte troops on Vienna and their ultimately unsuccessful siege of the city in $1683 .{ }^{13}$ Over the following decades, the Habsburgs were able to reconquer Hungary and large parts of the Balkans; for a period of roughly twenty years, they even held Belgrade. In the course of these wars, the imperial armies captured thousands of Ottoman troops who were subsequently either forced to work e.g. on galleys or in the construction of fortresses, or were sold to officers or private owners. ${ }^{14}$ In the case of wealthier prisoners of war, ransom was demanded if possible. ${ }^{15}$ This group of captives included Black men and women who had served in the Ottoman forces as soldiers, slaves, or in other functions. Two early documented examples of such persons in Vienna were the "Blackamoors" Balthasar - perhaps a defector or refugee, baptized in a solemn ceremony in St. Stephen's Cathedral in $1629^{16}$ - and Anton Studericus († 1649), who lived in the house of a commander deployed in the Great Turkish War. ${ }^{17}$ Several others are confirmed for the period after the Siege of Vienna when the imperial army counterattacked toward the southeast from 1684 to 1698: Hans Hirsch († 1684),

13 Cf. for example Marlene Kurz et al., eds., Das Osmanische Reich und die Habsburgermonarchie: Akten des Internationalen Kongresses zum 150-jährigen Bestehen des Instituts für Österreichische Geschichtsforschung (Vienna: Oldenbourg, 2005); Andrew Wheatcroft, The Enemy at the Gate: Habsburgs, Ottomans and the Battle for Europe (London: Pimlico, 2009).

14 An example from Jennersdorf in Burgenland: "The spoils won during a foray or raid are taken to market after the return, including the prisoners, and sold to the highest bidder. Anyone possessing a captured Turk has him shackled with an iron chain [. . .]." Josef Kametler, "Zeitzeugenberichte. Auszug aus dem Stadtbuch von Jennersdorf," in 800 Jahre Weichselbaum 1187-1987: Festschrift Wappenverleihung und Gemeindehauseinweihung am 5. Juli 1987 (Weichselbaum: Gemeinde Weichselbaum, 1987), 62.

15 On the bad treatment of and trade in the so-called Beutetürken (captured Turks) on location, both of which were largely beyond the authorities' control, see Karl Teply, "Vom Los osmanischer Gefangener aus dem Großen Türkenkrieg 1683-1699,” Süd-Ost-Forschungen 32 (1973): 33-72.

16 Sauer and Wiesböck, "Sklaven, Freie, Fremde," 21 and 24.

17 Sauer and Wiesböck, "Sklaven, Freie, Fremde," 24-25. 
Nicolaus Luschy († 1687), or the "Aithiopissa Turca” Anna Elisabeth (baptized 1690). ${ }^{18}$ The existence of such Black "captured Turks" seems to have mostly remained limited to eastern Austria, i.e. the region most heavily affected by the wars; ${ }^{19}$ only a single Egyptian from Suez (Johannes Franciscus Feldner, baptized in Steyr in1691) is mentioned outside of Vienna. ${ }^{20}$ Maria Elisabetha Neyrin, who married the Black court drummer Anton Monteur in Salzburg in 1706, constitutes no exception in this regard her parents had been captured by imperial troops in Hungary, and she herself had come to Salzburg from Vienna. ${ }^{21}$

Summarizing the existing information on this first group yields a clear picture of the procurement, social embedding and personal situation of the affected persons: They were Ottoman prisoners of war of African origin (with Balthasar possibly a refugee) who had come under the control of the imperial army and - since they were apparently not wealthy enough to pay for their freedom - were (forcibly) baptized and designated for permanent residence within the Habsburg sphere of power. ${ }^{22}$ In contrast to many other Ottoman captives, ${ }^{23}$ they rarely ended up in noble environments but instead in middle-class households linked to the circles of officers or clerics, especially those of wholesalers, innkeepers and church institutions. ${ }^{24}$ Once there, they were presumably put to work as domestics, since we find no evidence of the type of employment outside of the household that was possible for baptized Turkish captives. ${ }^{25}$ Nevertheless, they certainly contributed to exoticizing representation in everyday life as well - a Black servant or waiter at an inn may well have been attractive in a local context. They were also perceived by a wider public, especially during their spectacularly staged baptisms (two of which were even performed at St. Stephen's

18 On all of these individuals, see Sauer and Wiesböck, "Sklaven, Freie, Fremde," 25.

19 This was a characteristic situation for Ottoman prisoners of war in general: There are reports of 651 forced baptisms in Vienna alone, and of a further 117 in Graz; other "captured Turks" wound up in various small towns in Lower and Upper Austria, but never any further west. See Salvatore Bono, Schiavi: Una storia mediterranea XVI-XIX secolo (Bologna: Il mulino, 2016), 239-240.

20 Sauer and Wiesböck, "Sklaven, Freie, Fremde,” 53, note 100.

21 Sauer, "Neue Beiträge," 245.

22 For general information, cf. Manja Quakatz, “'Gebürtig aus der Türckey’: Zu Konversion und Zwangstaufe osmanischer Muslime im Alten Reich um 1700," in Europa und die Türkei im 18. Jahrhundert / Europe and Turkey in the 18th Century, ed. Barbara Schmidt-Haberkamp (Bonn: V\&R unipress, 2011), 417-430.

23 Teply states that a very high percentage of godfathers to "captured Turks" in Graz (two thirds) were nobles, but also points out that the corresponding percentage in Vienna was much lower. See Teply, "Vom Los osmanischer Gefangener," 56.

24 One exception may have been the "Turk and Blackamoor" Johannes Antonius Neukirchner, who was baptized by order of Emanuel Johann Anton von Liechtenstein, a prince of the Holy Roman Empire, in the Vienna Minoritenkirche (Friars Minor Conventual Church) in 1725. The prince was a Knight of the Order of Malta as well as being deployed in the Balkans, making multiple recruitment scenarios plausible in regard to Neukirchner.

25 Teply, "Vom Los osmanischer Gefangener," 60-63. 
Cathedral), i.e. in a religious-propagandistic, anti-Islamic context: In Balthasar's (1629) case, the focus was on demonstrating a successful "conversion," ${ }^{26}$ while the baptism of Anna Elisabeth (1690) was about substantiating the political allegiance of her owner, an Armenian wholesaler whose loyalty was sometimes questioned. With Johannes Antonius Neukirchner in 1725, it was once again conversion to Christianity that took ideological center stage. ${ }^{27}$ As was often the case in the context of "captured Turks," the aspect of triumph over the High Porte respectively over Islam played an important role. ${ }^{28}$ Aside from this context, however, no prestige-related functions of Black Ottoman captives are verifiable within the framework of the state's "representative publicity," which was enacted at a higher level of the hierarchy. The so-called Hofmohren of the aristocratic elites were recruited through different channels.

\section{Piracy in the Mediterranean}

One of these other channels was the European buccaneering activity in the Mediterranean, which had developed in parallel to that of the Ottoman and Barbary pirates since the crusades. ${ }^{29}$ African men and women were often found on ships belonging to the Sultan or other North African rulers that were seized on the Mediterranean Sea by the Sovereign Military Order of Malta or the papal fleet, as well as in captured cities along the coast and on individual islands. They were either forced into labor or sold, sometimes also gifted, to the Order of Malta itself or to affiliated noble families. "181 blackamoors, among them women and children, were a coveted prize," states the 1686 report on the conquest of a city by Admiral Johann Joseph v. Herberstein of the Order of Malta, who hailed from Styria. ${ }^{30}$ Occasionally, the victims of such activities

26 "When they had come to the church, he was asked publicly there before the people in different languages, like Turkish, Arabic, Slavic, and German, why he had come, and what was his intent? Thereupon he answered loudly in all languages that he wished to believe in God the Almighty and the Holy Trinity, to be baptized, and to be a Christian; as a sign of this he tore the turban off his head and cast it on the ground, cursed the Mohammedan sect, climbed down off the black horse, fell to his knees on the ground before the choirmaster, and asked with raised hands thrice for the holy baptism, which he was granted, and thereupon proceeding with the usual age-old ceremonies was baptized and named Balthasar. Afterwards he took off the Moorish habit, in place of which he was given a German coat and hat, and mounted before the church a different, beautiful white horse [. . . ]" (excerpted from Sauer, Von Soliman zu Omofuma, 21).

27 Sauer and Wiesböck, "Sklaven, Freie, Fremde," 25; Sauer, “Neue Beiträge,” 237.

28 Teply, "Vom Los osmanischer Gefangener," 56; Bono, Schiavi, 177.

29 Cf. Salvatore Bono, Piraten und Korsaren im Mittelmeer: Seekrieg, Handel und Sklaverei vom 16. bis 19. Jahrhundert (Stuttgart: Klett-Cotta, 2009).

30 "181 Mohren, darunter auch Frauen und Kinder, waren eine begehrte Beute." Theodor Graff, "Frà Johann Joseph von Herberstein, Generalkapitän der Malteserflotte: Sein Einsatz gegen die Türken in der Levante und in Dalmatien in den Jahren 1686 und 1687," Zeitschrift des Historischen Vereins für Steiermark 89/90 (1988-90), 105. 
also wound up in Habsburg territory, like the unnamed slave owned by the South Tyrolean Baron of Boimont (mentioned in 1573), the two adolescent servants to the PrinceArchbishop of Salzburg, Johann Ernst von Thun (mentioned in 1697 ff., one of them being the previously discussed Anton Monteur +1721$)$, or the Moroccan Joseph Reiske († 1777), who was allegedly captured by a Baron Mittrovsky. ${ }^{31}$

As with the first examined group of prisoners of war, the background for this second scenario was the conflict with the Ottoman Empire and its Islamic allies in North Africa. Nevertheless, the recruitment of "unfree personnel" by way of piracy had several specific characteristics. Geographically, its focus was not on the Balkans but on the Mediterranean; the routes of enslavement passed through Sicily or other important islands like Malta or Corfu. The protagonists were officers or commanders of the Christian fleets, often in the service of the Order of Malta, who gifted their captives - presumably youths - to family members on several occasions. The mentioned archbishop of Salzburg, for instance, received his "two under 15 years - pretty young blackamoors" from his brother Francis Sigmund, an admiral of the Order and commander of the papal fleet. He returned the favor by interceding for Francis Sigmund's appointment as field marshal. ${ }^{32}$ In these cases, family ties were more crucial to the choice of captives' destinations than prestige-related or similar considerations, and the affected prisoners thus wound up not in imperial Vienna but in other Habsburg lands like Tyrol, Salzburg, and possibly Styria in which the relatives of the military agents in the Mediterranean were members of the local elite. To avoid misunderstandings, it should be mentioned that the vast majority of the "Blackamoors" captured by Christian buccaneers remained in the Southern European and Mediterranean areas. ${ }^{33}$ Only few were sent to the Habsburg Empire (or perhaps elsewhere in Europe). These select few individuals, however, were employed in aristocratic milieus and were thus able to attain the status of Hofmohren in the actual sense - in contrast to the Black "captured Turks" from the continental war.

\section{Overseas Slave Trade}

Although individual instances of Black slaves in aristocratic circles are documented as early as the mid-fifteenth century, their instrumentalization for the purpose of exoticizing representation only became a trend in the closing decades of the seventeenth century when the family of Count Harrach, who had served as ambassador in Madrid, returned to Vienna from Spain with several dark-skinned domestics. Initially encountered only in the diplomatic milieu - we find sources e.g. on a Portuguese ambassador,

31 Sauer and Wiesböck, “Sklaven, Freie, Fremde,” 32.

32 “zwey Unter 15. Jahren - schöne junge mohren.” Sauer, “Neue Beiträge,” 240.

33 Bono, Piraten und Korsaren, in particular 252-255. 
and later on Spanish and British envoys- this form of representation soon also became popular among the members of the imperial family (Joseph I, Charles VI and his wife Elisabeth Christine) and the highest ranks of the Austrian nobility: Besides Harrach, examples are documented in the Kaunitz, Lobkowitz, Liechtenstein, Esterházy, Khevenhüller, Schrattenbach, Kolowrat, and Seilern families.

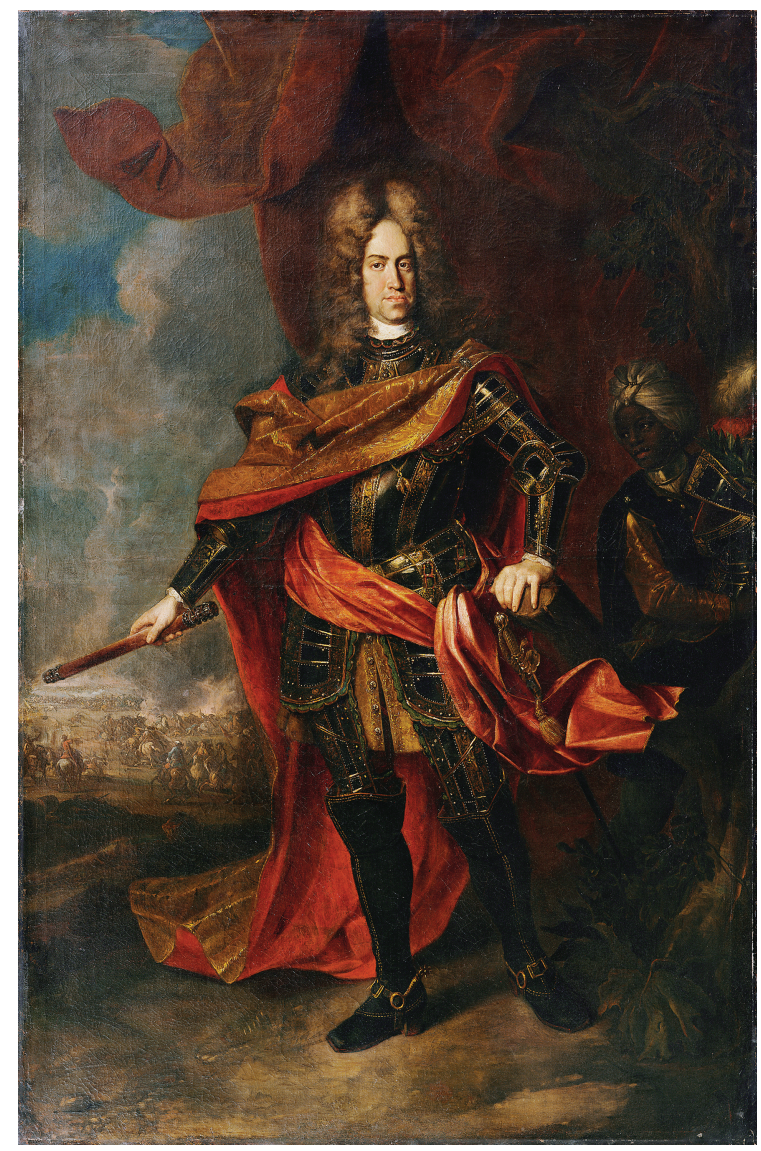

Fig. 6.1: Portrait of Emperor Charles VI accompanied by a "Moor," oil on canvas, by Johann Gottfried Auerbach, ca. 1720/1730. Österreichische Galerie Belvedere, made available under the Creative Commons Attribution-Share Alike 4.0 license.

The recruitment channel for these Hofmohren was the trade in slaves from overseas, and this trade occurred primarily via Portugal. The very first slave in the possession of an Austrian noble, Perablanco, was gifted to his master in Lisbon in 1451; whether he 
eventually made it to Austria is unknown, however. ${ }^{34}$ Somewhat later, there is mention of further persons with Portuguese backgrounds like Salvator Ravoncius ( + 1698), Jacob Bock (executed in the wake of the so-called Footman Revolt of 1704, presumably from Angola) or Peter Weiß († 1754, presumably from the Cape Verde Islands). ${ }^{35}$ As late as 1760, ambassador Johann Sigmund Graf Khevenhüller brought two Black men, one of them named Domingo, from Lisbon to Vienna. ${ }^{36}$ Spain was a further source. As mentioned above, Harrach came from Madrid with a group of "Blackamoors" - among them two women, Paula († 1677) and Emanuela $(† 1699)^{37}$ - and an "African" arriving in Innsbruck in 1705 on his way to Rome claimed to have been baptized in Spain. ${ }^{38}$ Having ruled Spain as regent from 1711 to 1713, (dowager) Empress Elisabeth Christine likely adopted the trend from there; as late as 1740, her entourage included two Black youths. ${ }^{39}$ Johann Ramurch († 1770) and Franciscus Moreno (last mentioned in 1777), servants to the Spanish ambassador, likewise had an Iberian background. ${ }^{40}$

As Europe expanded colonially, these established channels expanded and changed. Ferdinand Draber ( $†$ 1692), for example, the "Moorish hajduk" of a Dutch field marshal living in Vienna, may represent evidence of a connection to the Dutch Republic's slave trade in South Africa or Indonesia. ${ }^{41}$ Beginning in the early 1770s, the West Indian colonies of the British Empire likewise became important as regions for recruitment. Besides the Black footman of an English diplomat (Franciscus Hau +1774$),{ }^{42}$ the West Indies were also the origin of the "Blackamoors" of Count Seilern (Nikolaus Rock $\uparrow 1776$, Emanuel Farelli +1781 , Carl Pastan +1790$)^{43}$ as well as of a further servant of Khevenhüller's (Johann Malbring † 1805). ${ }^{44}$ The musician Friedrich Augustus Bridgetower, who spent several years at the court of the princes Esterházy in Eisenstadt respectively in the Hungarian town of Eszterháza (today: Fertöd), was presumably from the Caribbean. ${ }^{45}$

34 Walter Sauer, Expeditionen ins Afrikanische Österreich: Ein Reisekaleidoskop (Vienna: Mandelbaum, 2014), 29.

35 Sauer and Wiesböck, "Sklaven, Freie, Fremde," 26-29 and 32.

36 Sauer, "Neue Beiträge,” 238-239.

37 Sauer and Wiesböck, “Sklaven, Freie, Fremde,” 37.

38 Sauer, "Neue Beiträge," 244.

39 Sauer, "Neue Beiträge,” 235-237.

40 Sauer and Wiesböck, "Sklaven, Freie, Fremde," 32-33.

41 Sauer and Wiesböck, "Sklaven, Freie, Fremde," 25.

42 Sauer and Wiesböck, "Sklaven, Freie, Fremde," 33.

43 Sauer and Wiesböck, "Sklaven, Freie, Fremde," 33-34.

44 Sauer, "Neue Beiträge,” 239.

45 Sauer, “Neue Beiträge,” 239-40. 
As far as we know today, the Hofmohren of the high nobility were generally not from the Ottoman Empire ${ }^{46}$ but rather of African, South and East Asian or (later) AfroAmerican origin. At the political-symbolic level, they signified more than just the victory over a neighboring great power in the rivalry for Hungary and Southwest Europe: They stood for imperialist claims in the global context. It is therefore no coincidence that the eighteenth century as the golden age of the Hofmohren in part concurred with the Austrian Habsburgs' hope for hereditary succession in the Spanish Empire and in part went hand in hand with their own colonial aspirations in the Indian Ocean. ${ }^{47}$ Especially for Vienna, where Turkish prisoners had a lesser representative value than "Blackamoors," a further image-related aspect must also be taken into consideration - for there were already plenty of mere "Orientals" in the city, ${ }^{48}$ and effective outward representation therefore required something more, namely "Black" skin.

\section{Early Colonial Activity by the Habsburg Monarchy}

A final group of persons from overseas to be mentioned here was linked to the Habsburg efforts at colonization. An important institution in this regard were the Jesuit missions in South and East Asia, in which Austrian members of the order were prominently involved. ${ }^{49}$ If we give credence to the declaration of origin "from the island of China” (i.e. Macao), this connection appears feasible as early as in the case of Johann

46 An exception to some extent was the Turkish girl that Maria Theresa had bought out of slavery. See Irene Montjoye, Maria Theresias Türkenkind: Die abenteuerliche Lebensgeschichte der Anna Maria Königin, Vienna: Czernin 2000. This episode should be viewed as more of an accompanying phenomenon to the redemption of Christian slaves in the Ottoman Empire. On this redemption, cf. Elisabeth WatzkaPauli, Triumph der Barmherzigkeit: Die Befreiung christlicher Gefangener aus muslimisch dominierten Ländern durch den österreichischen Trinitarierorden 1690-1783 (Göttingen: V\&R unipress, 2016).

47 On the general context, see Karl Vocelka, Glanz und Untergang der höfischen Welt: Repräsentation, Reform und Reaktion im habsburgischen Vielvölkerstaat (Vienna: Ueberreuter, 2001), 67-101.

48 A source from the 1780s states: "The original Viennese have disappeared. A lovely spectacle is afforded by the different national costumes. The city is not in the uniform $\mathrm{G}$ e $\mathrm{r} \mathrm{m}$ a $\mathrm{n}$ garb like the other cities. We encounter the stiffly striding Hungarian with the fur-embellished Dolman, the tightfitting pants and mighty long braid, the round-headed Pole with monkish haircut and fluttering sleeves. Armenians, Walachians, and Moldavians with half-oriental wardrobe are not rare; the VanDyke-bearded Rascians occupy an entire street; the Greeks in loose clothing smoke in groups in the coffee houses around Leopold (now Ferdinand) Bridge, and the bearded Muslims, with their broad murder knives in their belts, trot heavily in yellow clogs through the dirty or dusty streets [. . .]," reprint by Wilhelm August, "Wien vor einem halben Jahrhundert. Fortsetzung," Der österreichische Zuschauer, August 30, 1839, 1057, emphasis according to the original source.

49 Cf. Gustav Otruba, “Österreichische Jesuitenpatres des 17. und 18. Jahrhunderts in der Weltmission und als Erforscher der Erde,” Österreich in Geschichte und Literatur 5, no. 1 (1961): 29-39. 
Franzisch († 1686). ${ }^{50}$ The missionary context is even more obvious for Johann Baptist Somoß ( $†$ after 1748), however; his children were baptized by relatives of the Jesuit missionary and later bishop of Nanking, Gottfried von Laimbeckhoven, and Somoß himself was sponsored by them in Vienna at least for some time. ${ }^{51} \mathrm{~A}$ further potential connection may have been established through the (Zweite) Österreichische Ostindien-Compagnie, which in 1780 operated profitable trading posts in the Mozambican Delagoa Bay, on the Nicobar Islands, and in India..$^{52}$ It seems plausible that natives of these regions could have been brought to Austria aboard trading ships, like the fifteen-year-old Victoria Arcate from southeast India ( +1789$).{ }^{53}$ The migration of Michael Anjou († 1799), who hailed from Mauritius or the Malabar coast and arrived in Vienna concomitantly with a natural scientific voyage to the Indian Ocean undertaken by imperial order, may have followed this route as well. The fact that vice court and state chancellor Count Cobenzl organized lodging, teaching and baptism preparations for the "petit garcon indien" on the emperor's behalf in 1788 would seem to corroborate this connection. ${ }^{54}$

Whether these individuals were slaves or undertook some form of voluntary migration remains unknown. It is noteworthy, however, that the members of this group were not employed as Hofmohren in the service of the high nobility but instead put to work in commercial (Johann Franzisch as the domestic of a baker, Johann Baptist Somoß as a tailor) or other middle-class, perhaps also medical or scientific environments (Victoria Arcate for a doctor). Michael Anjou likewise did not serve in the inner circles surrounding Joseph II, instead becoming an animal keeper at the Schönbrunn menagerie..$^{55}$

50 Sauer and Wiesböck, "Sklaven, Freie, Fremde," 25.

51 Sauer and Wiesböck, "Sklaven, Freie, Fremde," 30-31; cf. Stephan Puhl and Sigismund von Elverfeldt-Ulm, eds., Gottfried von Laimbeckhoven SJ: Der Bischof von Nanjing und seine Briefe aus China mit Faksimile seiner Reisebeschreibung (Nettetal: Steyler, 2000), 28-29, 89 (with further literature). Laimbeckhoven's account of his journey from Portugal via Mozambique to China was also printed: Neue Umständliche Reiß- Beschreibung. Von Wienn nach China abgeschickten Missionarii. Darinnen dessen ungemein beschwär- und gefährliche Schiffahrt von Genua bis Macao mit beygemengten vielen gar Lehrreichen Astronomisch- und Geographischen Anmerckungen etc. (Vienna: Prasser, 1740).

52 See in particular Stefan Meisterle, "Von Coblon bis Delagoa: Die kolonialen Aktivitäten der Habsburgermonarchie in Ostindien” (PhD diss., University of Vienna, 2014), http://othes.univie.ac. at/35012/.

53 Sauer and Wiesböck, "Sklaven, Freie, Fremde," 35.

54 Sauer and Wiesböck, "Sklaven, Freie, Fremde," 34-35.

55 Biographical note: After his death in 1799, Anjou's body was consigned to the imperial Naturalienkabinett (natural objects collection) and taxidermized without burial despite the protests of the competent parish priest and a considerable public outcry; like Angelo Soliman, whose corpse been stuffed in 1796, Anjou ended up as a museum object, dressed up and riding a camel. See Sauer and Wiesböck, "Sklaven, Freie, Fremde," 34-35. 


\section{The Life of the "Exotic" Domestics in the Aristocracy's Service}

When examining the situation of the "exotic" domestics employed by the upper echelons of Austrian nobility, we thus find two principal scenarios concerning their recruitment: the European pirate activity in the Mediterranean on the one hand and various routes of slave trading with overseas territories on the other. The ultimate destinations of the affected individuals differed in accordance with their region of origin: Persons captured on the waters or the shores of the Mediterranean Sea generally wound up with noble families of regional importance (and therefore in the crown lands), while those purchased from overseas tended to end up in the service of the high aristocracy and thus largely in the capital of Vienna - an indication of the political significance of their representation potential. ${ }^{56}$ For the final decades of the eighteenth century, other paths for immigration outside of the established trade routes are also imaginable, e.g. as "souvenirs" from expeditions; we will deal with this aspect again later. In one particular case, we can even speak of a form of "freedom of travel": For Friedrich Augustus Bridgetower, the Esterházy court in western Hungary merely represented a stopover on his journeys between Germany, Poland, and England.

Even though the available sources offer little information on the existence of Black men and women outside of the noble courts, servant labor in aristocratic households certainly appears to have been the most important occupational niche for this group of immigrants during the early modern period. While the affected individuals found themselves restricted to domestic, servile functions, they at least performed them in a socially highly prestigious sector. Accordingly, their outwardly visible living conditions seem to have been quite decent - no self-respecting noble family wished to see any but well-shaped, well-fed and well-dressed (and of course adaptable and obedient) Hofmohren in their immediate environment, and only those conforming to these requirements could contribute positively to the prestige of their masters. Endowment with particularly splendid clothing (Angelo Soliman, Jean Sibas) or private quarters (Johann Michael Martin † 1719), the providing of education (Elisabeth Christine's "Blackamoors," Anton Monteur) or medical care (the woman named Paula in the service of the Harrachs, Elisabeth Christine's "Blackamoors," and Johann Malbring), and symbolic gestures of acceptance like the willingness of prominent persons to baptize their Black servants' children (Johann Michael Martin, Anton Monteur) can be viewed as signs of a certain privilege compared to other staff.

In contrast to the case of the African "captured Turks" in the middle-class and lower noble milieus, the representative value of the Hofmohren lay not only in the

56 The two "Blackamoors" in Eisenstadt, Sibas (last mentioned in 1771) and Bridgetower (last mentioned in 1785), do not constitute counterexamples. The Princes Esterházy were among the most important magnates in the Kingdom of Hungary and thus members of the elite of the Habsburg Monarchy. 
exoticization of their masters' immediate environment but also in their broader publicity impact. The conspicuity of their dark skin was used to great effect during the spectacular pageants held by the emperor and the aristocracy - as documented in written reports like the one by Gerald Schlag quoted at the beginning of this article as well as in pictorial accounts (especially concerning Jean Sibas and Angelo Soliman). A revealing detail in this regard can be found in the sources on the two youthful servants to Elisabeth Christine: They were assigned to a burgher for board and lodging who was obligated to ensure not only their clothing, education and medical care but also their punctual participation in the public appearances of the dowager empress (!). Emanuel Soesa and Anton Monteur served as timpanists in the orchestra of the prince-archbishop of Salzburg, thereby likewise assuming a distinguished position. Whether the numerous portraits of nobles "with black servant" (an important source for biographical research) were intended for broader publicity effects or rather for internal court use is debatable; the many portraits of Charles VI depicting him together with his footman Johann Michael Martin, however, were distributed to friendly courts throughout the Habsburg Monarchy and Europe (Fig. 6.1). Two cases in which copperplate portraits of African servants (Joseph Reiske, Angelo Soliman) were reproduced and distributed are also documented..$^{57}$

Which specific propagandistic effects were intended with the public display of Black domestics is difficult to reconstruct, but the fact that global networks and considerable wealth were required to bring these exotic "foreigners" to Baroque Europe was certainly apparent to all contemporaries. The lengthy inscription on the widely disseminated portrait of Angelo Soliman (presumably created in 1764), intended for persons educated in the humanities, also indicates motives of domestication, civilization, and domination while simultaneously referring to the master's wish to distinguish himself politically: Described as "os humerosque Jugurthae similis" (similar in stature and face to Jugurtha), Soliman is identified with the powerful adversary of Rome during the late second century BC. In addition, an analogy is drawn between his master, the Prince of Liechtenstein, and Gaius Marius, the reformer of the Roman military who defeated Jugurtha - a homage to the prince, who was indeed accustomed to being revered as a "second founder of the city" like Marius. ${ }^{58}$

57 On such portraits, see Viktoria Schmidt-Linsenhoff, "Mit Mohrenpage," in: Ästhetik der Differenz: Postkoloniale Perspektiven vom 16. bis 21. Jahrhundert. 15 Fallstudien (Marburg: Jonas, 2014), 1:249-266.

58 On this, see Walter Sauer, “Angelo Soliman: Mythos und Wirklichkeit,” in Sauer, Von Soliman zu Omofuma, 62. 


\section{Middle-Class Desires for Representation and the Procurement of Black Servants}

In the late eighteenth century, the conditions for procurement of Black domestics began to change dramatically. Slavery had been abolished, or was in the process of being abolished, in all European countries (though not necessarily in their colonies). ${ }^{59}$ In the Habsburg lands, the prohibition of slavery was included in the Allgemeines Bürgerliches Gesetzbuch (General Civil Code) in 1811. Four years later, the Congress of Vienna outlawed trade in slaves as well. European pirate activity in the Mediterranean had been deprived of its base as a result of Napoleon's capture of Malta and the later cession of the island to the British Empire; in order to secure the "freedom of the seas," the Congress of Vienna resolved to counter the attacks by Ottoman and North African "pirates" by way of military assaults on the port cities they were staged from. ${ }^{60}$ This effectively closed off the associated route for the procurement of Black servants as well.

Nevertheless, a certain "exotic" flair in the outward appearance of the rich and powerful continued to hold considerable allure. A report on the participation of Emperor Francis I's daughter-in-law (who would later become Francis Joseph's mother) in the opening of the Hungarian Diet in 1825 states: "Sophie, who is bedazzled by all the splendor of the magnates and their costumes [. . . ] and admires in amazement the silver-harnessed horses and luxurious carriages of Prince Batthyány, whom his gold-laced lackeys accompany together with the 'most beautiful negro' the Archduchess has ever seen, dressed in blue-yellow-white and silver." ${ }^{61}$ And it was not just the aristocratic and imperial circles in which this traditional desire for representation was apparent. The fashion of employing Black personnel had already spilled over to the bourgeois classes, whose cultural behavior generally tended to imitate the nobility. Examples from Vienna can be found as early as in the final quarter of the eighteenth century (like Johann Emanuel +1781 , who worked for a wholesale merchant and banker), ${ }^{62}$ and as the following paragraphs will show, the demand remained steady despite the altered political conditions.

It was a true dilemma: On the one hand, there was significant demand for persons with exotic representation potential in even broader circles than before, but on

59 For an overview, see S. Daget, "The Abolition of the Slave Trade," in Africa in the Nineteenth Century Until the 1880s, ed. J. F. Ade Ajayi, (Paris: UNESCO, 2000), 64-89.

60 Walter Sauer, "Habsburg Colonial: Austria-Hungary’s Role in European Overseas Expansion Reconsidered,” in Austrian Studies 20 (2012): 18-19.

61 "Sophie, die von all der Pracht der Magnaten und ihrer Kostüme geblendet ist [. . .] und staunend die silbergeschirrten Pferde und die Prachtkarossen des Fürsten Batthyány bewundert, den seine Lakaien goldbetreßt geleiten, zusammen mit dem in blau-gelb-weiß und Silber gekleideten 'schönsten Neger', den die Erzherzogin je gesehen.” Egon Caesar Conte Corti, Vom Kind zum Kaiser (Graz: Pustet, 1950), 11.

62 Sauer and Wiesböck, "Sklaven, Freie, Fremde," 34. 
the other hand, the traditional routes of recruitment - slave trade and various forms of war captivity - had been closed. A "legal” way out of this quandary soon emerged in the shape of a new scenario that built on Europe's growing colonial influence in overseas regions and the better shipping connections to them. Prospective buyers and their representatives increasing made use of the possibility of traveling to Africa, Asia or the Americas themselves for purposes of business, tourism or science; while there, they were able to obtain exotic servants directly.

The fact that voluntary migration from overseas to Europe respectively Habsburg Austria (mostly in search of employment) simultaneously increased is not to be downplayed; although the entertainment industry was the service sector that accepted the majority of these immigrants, ${ }^{63}$ some of them likely also found work as household servants. But new forms of recruiting Black domestics in the traditions of feudal representation behavior were nevertheless established. Whether this made the affected individuals any "freer," respectively in which ways the previous master-servant relationship shifted towards an employer-employee relationship, will be discussed in more detail later.

For the Austrian Empire established from the Habsburg territories in 1804, Brazil was the first new region of origin to appear. In order to bind the Portuguese royal family to the Habsburg court after it had fled to South America from Napoleon, Emperor Francis's daughter Leopoldine had been married to the Brazilian heir to the throne, Dom Pedro, in 1817. Close economic and scientific ties were the result. ${ }^{64}$ Not only did Leopoldine send home minerals and plants for the imperial collections, she also gifted her brother Francis Charles a young Afro-Brazilian, who arrived in Vienna in 1820: Emmanuel Rio (Fig. 6.2) ${ }^{65}$ Besides these rather antiquated carryings-on reminiscent of royal customs in previous centuries, she also mediated the induction into a military orchestra in Venice of two Black slaves whose attempt to escape had failed. ${ }^{66}$ Scientific journeys were undertaken as well: Johann Emanuel Pohl, a prominent participant in the Austrian Brazil expedition, brought two Aimore or so called Botocudos (João and Francisca) to Vienna in $1821,{ }^{67}$ and the naturalist Johann Natterer returned from Brazil in 1836. As was the local tradition, he had purchased several male and

63 On a specific subsector, see Walter Sauer, "Exotische Schaustellungen im Wiener Vormärz: Zwischen Voyeurismus und früher Rassentheorie," Mitteilungen des Instituts für österreichische Geschichtsforschung 124, no. 2 (2016): 391-417.

64 Carlos H. Oberacker, Leopoldine: Habsburgs Kaiserin von Brasilien (Vienna: Amalthea, 1988).

65 Ina Markova and Walter Sauer, "Waldhornblasender Gärtner: Ein schwarzer Brasilianer im vormärzlichen Österreich. Oder: Vom Wilden zum Weltbürger und wieder zurück?” Wiener Geschichtsblätter 66, no. 2 (2011): 95-110.

66 Hansjörg Rabanser, “'Mit einem krummen Pferd und einem einhändigen Gutscher.' Die Venedig-Reise der Familie Vogl im Jahr 1835,” in Wissenschaftliches Jahrbuch der Tiroler Landesmuseen 5 (2012): 412-443.

67 Sauer, “Schaustellungen,” 398. 
female slaves during his years in the country, some of whom hailed from Mozambique. Three of them (Laureana, José, Candido) accompanied him to Vienna. ${ }^{68}$

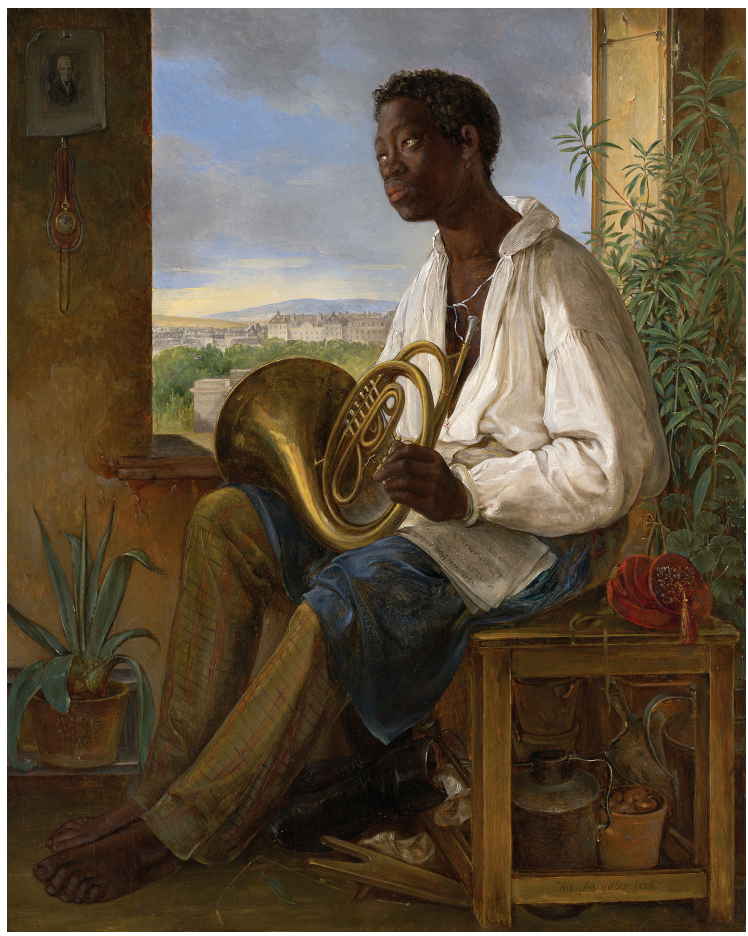

Fig. 6.2: Portrait of Emmanuel Rio, oil on panel, by Albert Schindler, 1836. The Art Institute of Chicago, made available under the Creative Commons Zero Public Domain Designation.

Somewhat later, the African region encompassing Egypt, Sudan, and Ethiopia became the prime target of Austrian economic and colonial interests, and Austrian travelers increasingly began to bring children back with them from the area. Early examples of this practice were one Paolo from Dongola, whom the Austrian specialist for the Orient, Anton Prokesch, had purchased in Elephantine in 1830, ${ }^{69}$ and around nine years later an “African negro boy from Sennaar” named Ramadah, obtained by

68 Kurt Schmutzer, Der Liebe zur Naturgeschichte halber: Johann Natterers Reisen in Brasilien 1817-1836 (Vienna: Verlag der Österreichischen Akademie der Wissenschaften, 2011), 119-122.

69 Anton Prokesch-Osten jun., ed., Aus dem Nachlasse des Grafen Prokesch-Osten, Briefwechsel mit Herrn von Gentz und Fürsten Metternich I (Vienna: Gerold 1881), 346 and passim. On Prokesch, see Daniel Bertsch, Anton Prokesch von Osten (1795-1876): Ein Diplomat Österreichs in Athen und an der Hohen Pforte. Beiträge zur Wahrnehmung des Orients im Europa des 19. Jahrhunderts (Munich: Oldenbourg, 2005). 
Count August von Breuner during a hunting trip in Sudan. ${ }^{70}$ The following year, a population census in Vienna saw an eight-year-old from Egypt or Ethiopia registered as a "servant" to the Greek wholesaler Demeter Theodor Tirka under the name Oreste (later Orest Rihs † 1888). ${ }^{71}$

The number of Black children arriving in Austria in the company of noble and especially of middle-class travelers increased even further during the 1850s. The journalist Ludwig August Frankl, for example, purchased a boy in Jerusalem for 400 gulden, ${ }^{72}$ and the physician August von Genczik from Linz, who served as a military doctor in Khartoum, returned with "three representatives of African races of humans." 73 Two Black male youths named Ali and Said, whom Archduke Ferdinand Maximilian had brought with him from Egypt, were baptized in Trieste in $1856,{ }^{74}$ and an industrialist by the name of Weidman returned from the opening of the Suez Canal in 1869 with a young Egyptian (Mohamed Medlum † 1918, Fig. 6.3). ${ }^{75}$ The list could be continued at length. Youths from Sudan and Somalia were apparently also occasionally used for linguistic research. ${ }^{76}$

The "souvenirs" in practically all of these cases were underage, and the vast majority of them were boys. Young women, on the other hand - with a scant few exceptions like that of the Silesian prince Hermann von Pückler-Muskau, who caused a considerable stir in Vienna with his exceedingly young mistress ${ }^{77}$ - were "exported" only by missionaries, with more than eight hundred such cases (!) documented for the 1850s alone. This episode, which can only be mentioned in passing here, is certainly among the most appalling chapters in the history of human trafficking in Austria after the official abolishment of slavery. ${ }^{78}$ With support from Sardinian, French

70 Walter Sauer, "Egyptian Migration to the Habsburg Empire in the 19th Century," in Egypt and Austria III: The Danube Monarchy and the Orient. Proceedings of the Prague Symposium 2006, ed. Johanna Holaubek, Hana Navrátilová, and Wolf B. Oerter (Prague: Set Out, 2007), 207-218, here: 208.

71 A publication on this research conducted by Günter Haring, Alfred Kreisa and the author is in preparation.

72 Louise Hecht, Ludwig August Frankl (1810-1894): Eine jüdische Biographie zwischen Okzident und Orient (Cologne: Böhlau, 2016), 291-321.

73 Cajetan Felder, Erinnerungen eines Wiener Bürgermeisters (Vienna: Forumverlag, 1964), 110.

74 Zgodnja Danica, April 3, 1856.

75 Christine Sulzbacher, "Beten - dienen - unterhalten: Zur Funktionalisierung von Afrikanern und Afrikanerinnen im 19. Jahrhundert in Österreich,” in Sauer, Von Soliman zu Omofuma, 103-104, 76 Peter Rohrbacher, "Franz Xaver Logwit-lo-Ladu (1848-1866): Seine Bedeutung als afrikanische Gewährsperson in der Frühphase der österreichischen Afrikanistik," in Afrikanische DeutschlandStudien und deutsche Afrikanistik - ein Spiegelbild, ed. Michel Espagne, Pascale Rabault-Feuerhahn, and David Sim, (Würzburg 2014), 49-72; Sulzbacher, "Beten - dienen - unterhalten,” 104-105.

77 Ernst Joseph Görlich, “Eine äthiopische Fürstentochter in Wien,” Wiener Geschichtsblätter 28 (1973): 84-86; Sulzbacher, "Beten - dienen - unterhalten,” 101-102.

78 For general information, cf. Ute Küppers-Braun, "P. Nicolò Oliveiri und der (Los-)Kauf afrikanischer Sklavenkinder," Schweizerische Zeitschrift für Religions- und Kulturgeschichte 105 (2011): 141-166; Maria Magdalena Zunker, “Drei 'arme Mohrenkinder' in der Benediktinerinnenabtei St. 


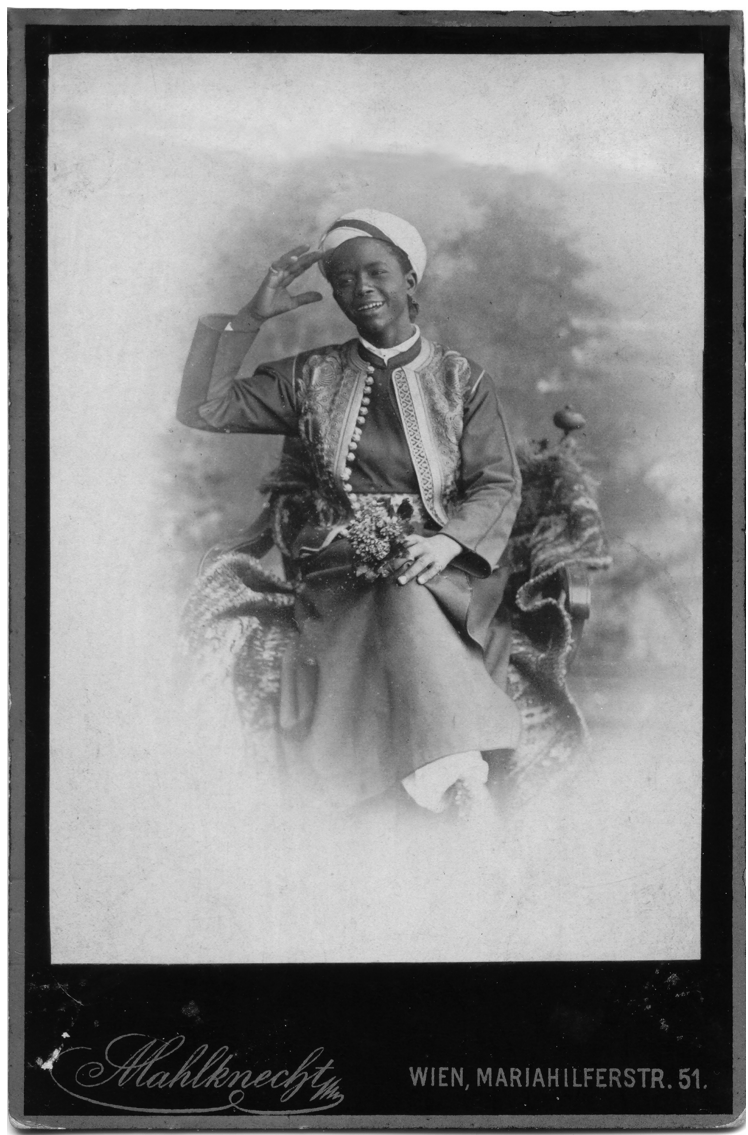

Fig. 6.3: Mohamed Medlum, manservant to a Viennese industrialist, photography, ca. 1900, unknown provenance.

and (initially) Austrian authorities, the Italian secular priest Nicolò Olivieri systematically purchased children - almost all of them girls between the ages of six and fourteen from slave markets in Egypt and passed them on to Southern and Central European women's convents for "catholic upbringing.” Associated journalists and priests secured the required donations by way of articles and public relations. 84 "imported" girls, most of them from Egypt, Sudan and Ethiopia, lived in Austrian nunneries in 1855 alone -

Walburg, Eichstätt: Eine Spurensuche," Studien und Mitteilungen zur Geschichte des Benediktinerordens und seiner Zweige 114 (2003): 481-532. On Austria in particular, see Sulzbacher, “Beten - dienen unterhalten,” 113-123; Walter Sauer, “'Mohrenmädchen’ in Bludenz, 1855-1858: Ein Beitrag zur Geschichte der afrikanischen Diaspora in Österreich,” Montfort: Vierteljahresschrift für Geschichte und Gegenwart Vorarlbergs 56, no. 4 (2004): 293-300. 
many in Lombardy-Venetia and Tyrol, others in Klagenfurt, Ljubljana, Škofja Loka, Zagreb, Salzburg, Vienna, Budapest, and other cities. ${ }^{79}$ Most of these children died tragically after a few years, and only a small number were eventually able to return to Egypt.

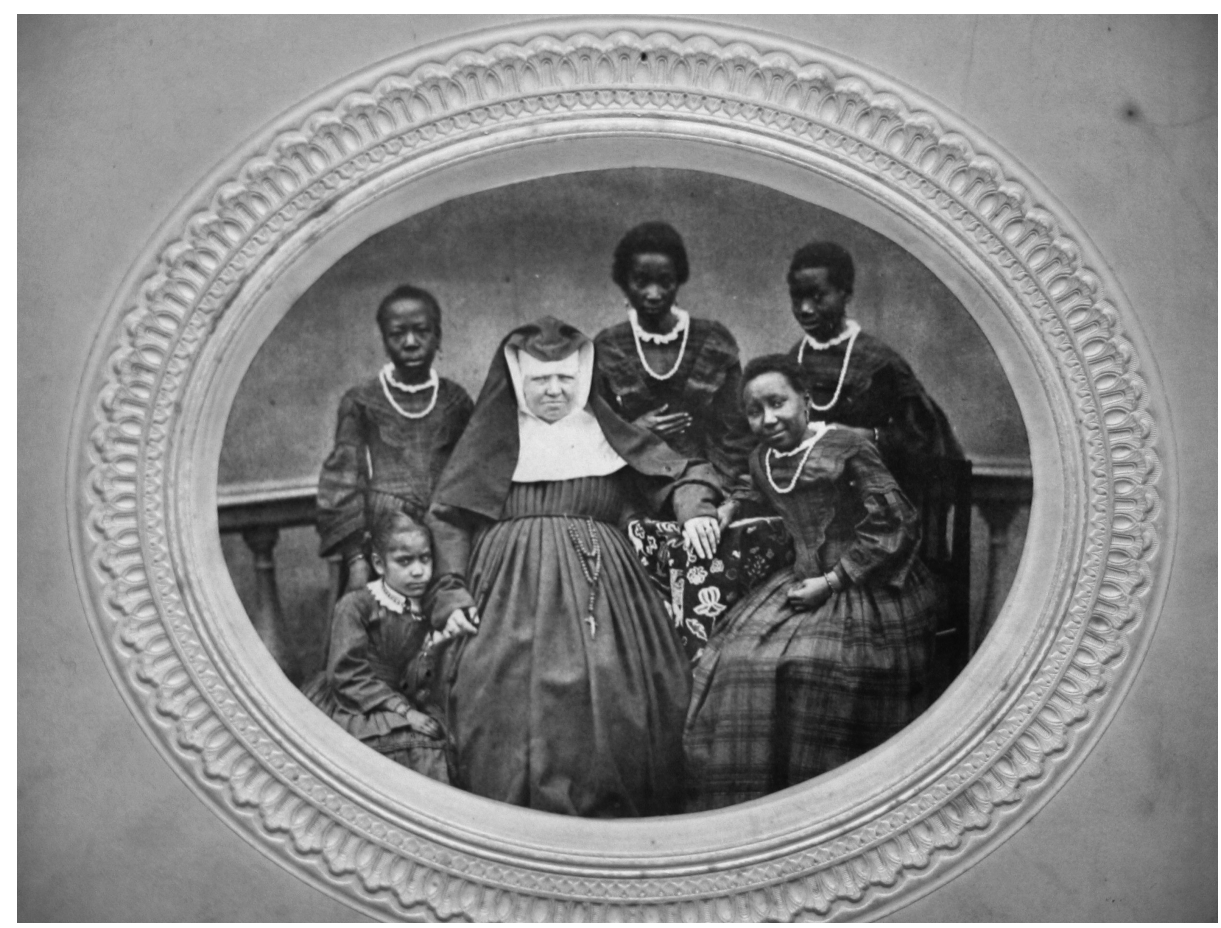

Fig. 6.4: Mater Constantia Gayer with the African girls, late 1850s, Ursuline convent Klagenfurt am Wörthersee.

Let us recap this new scenario: Despite the abolition of slave trade and the end of the military confrontation with the Ottoman Empire, the supply of Black youths from the Levant and Africa did not dry up; in fact, it may even have increased in volume. There was perhaps a trend towards younger men and women and even children being sent to Austria, and the "exotic" individuals were more frequently installed in middle-class and (in the case of many girls) ecclesiastic environments. What do we know about recruitment in the areas of origin, which was mostly conducted by European travelers and missionaries? In some cases, the decision to join these foreigners may have been made voluntarily by the respective children or their parents (an aspect already encountered in the situation during the late eighteenth century). It is far more likely, however -

79 Wiener Kirchenzeitung, October 21, 1856. 
and documented with some frequency - that these African children were young slaves offered for sale on corresponding markets. Pohl's Aimoré were prisoners of war, ${ }^{80}$ and Natterer himself stated in letters that he had purchased slaves. ${ }^{81}$ Paolo was likewise reported to have been "bought," ${ }^{2}$ and his compatriot Ramadah is described as a "negro slave [!] now in the service of the Lord Count." ${ }^{83}$ For the "mission girls," this state of affairs applied by definition, since they were to be bought out of "twofold slavery," namely physical enslavement and that of "heathendom." There are hardly any reports on the actual local situation, however, with only author Ludwig August Frankl describing a scene in Jerusalem in 1855 that was perhaps not unusual for the time:

The following day a black boy was brought to me at the hotel. He was of true beauty regarding his physique; and reminded me of the shape of the Appollino in the Palazzo Pitti in Florence. It was as if an artist had reproduced him from black ebony [. . . ] The boy was named Musa Said Saad Sruh Achmet Abdallah [. . . I I had available 400 fl. from a man who had informed me of his wish to own a black boy, and that was the sum I paid to the owner of the little slave. ${ }^{84}$

We can safely assume that the vast majority of these youths were already slaves prior to their acquisition by the European travelers. The practice of procuring "exotic" servants in the nineteenth century therefore differed from the procedure in preceding periods primarily in that the purchases were no longer made in Europe but on location (in Brazil or Africa) and thus outside of - or on the fringes of - the area of validity of European anti-slavery laws. ${ }^{85}$ Of course, according to the Austrian laws slaves were automatically considered free men and women once they set foot on an Austrian ship or on Austrian territory. ${ }^{86}$ But besides the fact that the border

80 Sauer, "Schaustellungen," 398.

81 Schmutzer, Der Liebe zur Naturgeschichte halber, 119-122.

82 Prokesch-Osten jun., Aus dem Nachlasse des Grafen Prokesch-Osten, 346.

83 "Negersclave [!] itzt in Diensten des Herrn Grafen." Sauer, "Egyptian Migration to the Habsburg Empire," 208.

84 "Am folgenden Tage wurde mir ein schwarzer Knabe in's Hotel gebracht. Er war von wahrhafter Schönheit, was seine Gestalt betraf; und mahnte mich an die Gestalt des Appollino im Palazzo Pitti zu Florenz. Es war, als hätte ein Künstler ihn aus schwarzem Ebenholze nachgebildet [. . .] Der Knabe hieß Musa Said Saad Sruh Achmet Abdallah [. . . ] Ich hatte von einem Herrn, der mir den Wunsch mittheilte, einen schwarzen Knaben zu besitzen, 400 fl. zur Verfügung und dieß war die Summe, die ich dem Besitzer des kleinen Sklaven zahlte.” Ludwig August Frankl, Nach Jerusalem! (Vienna, 1858), 3:209-210. The purchasing procedure extended over several days (ibid., 204-210).

85 Even this must be put into perspective for Olivieiri's young women, for they were paid for by the Austrian convents that took them in; these payments were officially declared as remuneration for expenses incurred by the missionary, not as payments for purchase.

86 Friedrich Harrer and Patrick Warto, "Das ABGB und die Sklaverei," in 200 Jahre ABGB: Die Bedeutung der Kodifikation für andere Staaten und andere Rechtskulturen, ed. Michael Geistlinger et. al. (Vienna: Manz, 2011), 283-290. 
authorities could be relied on to turn a blind eye in this regard, ${ }^{87}$ the notion of personal freedom remained a largely irrelevant concept to the enslaved children in practice. Being underage, they were dependent for many years on the care provided by the (prestigious) families that took them in; as foreigners, they were not integrated into Austrian society; and as servants, they were subject (until 1920) to strict regulations and were hardly prepared for an independent existence. While they may have thus been free in theory, they effectively found themselves in a state of familyembedded dependency that scarcely differed from that of the slaves in eighteenthcentury Europe. It was only the gradual societal changes that allowed some of them to achieve personal emancipation, especially in cases where the circumstances were favorable (for example Orest Rihs by way of his childhood friendship with a wellknown liberal industrialist and politician, or Mohamed Medlum through an unexpected sizable inheritance). The alternative for the majority of less fortunate former slaves was a precarious existence marked by unemployment and poverty.

The justification on the part of the purchasers may often have been that they were acting out of pity considering the often tragic fates of the youths they acquired and wished to make a personal contribution to thwarting slavery in the home countries of the children. The former argument cannot be entirely discounted, particularly since the notion of abolishing slavery had never managed to prevail in Austria over that of the redemption of slaves, which was deep-seated in the traditional Catholic milieus. ${ }^{88}$ The latter reasoning was occasionally already disputed by contemporaries, however - for instance in 1859 by the Austrian consular-general in Alexandria, Gustav Ritter von Schreiner:

One may look at the situation whichever way one likes, the negro children are purchased as slaves and ensnared as slaves, and the English government would always and sight unseen identify the process as formal slave trade because it acts on the perhaps not entirely incorrect principle that the more slaves are sold on the coastlines, the more interest the slave traders have in buying further slaves in the heartland of Africa and bringing them to the coast. ${ }^{89}$

87 Alison Frank, "The Children of the Desert and the Laws of the Sea: Austria, Great Britain, the Ottoman Empire, and the Mediterranean Slave Trade in the Nineteenth Century," American Historical Review 117, no. 2 (April 2012): 410-444.

88 Among the few examples for abolitionism was Johann Pezzl with his novel Faustin published in 1783. Likewise interesting in this context is the reporting during the 1820s in the journal Archiv für Geschichte, Statistik, Literatur und Kunst edited by Joseph von Hormayr, which advocated free trade while simultaneously welcoming the English Free Sugar Society's request to favor products manufactured exclusively using wage labor over those produced in part by slaves. See Caroline Wolfram, "Außereuropäische Einflüsse auf die bürgerliche Öffentlichkeit des frühen Vormärz und den österreichischen Frühliberalismus” (master’s thesis: University of Vienna, 2018), 61, http://othes.univie. ac.at/51022/).

89 "Man mag die Sache ansehen, wie man will, die Negerkinder werden als Sklaven angekauft und als Sklaven verführt, und die englische Regierung würde den Vorgang stets ungeschaut als förmlichen Sklavenhandel bezeichnen, weil sie von dem vielleicht nicht ganz unrichtigen Grundsatze 


\section{Conclusion}

Did the representation behavior of the nineteenth-century middle classes differ from that of the aristocrats of former times? Presumably it did so only in nuances. It was still the "exotic" appearance of the affected individuals, exhibited in the "Black" color of their skin and occasionally emphasized by Oriental-looking outfits, that mattered. The following was written about Mohamed Medlum (Fig. 6.3), for example: "As local tradition dictated, it was his task to serve the guests at table and, during carriage rides taken by his lord, to sit in a gold-embroidered uniform, with a red fez on his head and his arms crossed, behind the carriage-driving master and his wife. Medlum became popular as the 'Blackamoor of Hietzing' or the 'Weidman-Muhrl'."90 The members of the high society who could afford to buy children or servants from overseas were by no means interested in having their traditional lifestyle challenged in a multicultural fashion - their intent was not respect and mutual approach, but rather to enrich their outward appearance with "exoticism." Black domestics had the potential to increase the prestige of their owners, serving as indicators of the latter being well-traveled, perhaps even possessing sophistication or a philanthropic attitude. An educational intent to "civilize" can also be detected (e.g. in the case of Emmanuel Rio, who initially enjoyed an excellent education in Vienna before being transferred to the military, where he died). ${ }^{91}$ These types of motives appear to have become less frequent following the victory of the reaction in 1848, when discourses claiming an inherent, racially predetermined "savagery" of non-European peoples and polemics against humanist tendencies increasingly abounded. The fact that reports about denigrations and severe discrimination are more frequent for this period may be owed to better source preservation, but is also an indication of increasing intransigence and a "racialization" of the average consciousness and the media. One example of this is Ludwig August Frankl's report on Musa Said Saad Sruh Achmet Abdallah:

ausgehe, daß je mehr Sklaven an den Küstenstrichen verkauft werden, desto mehr Interesse die Sklavenhändler haben, neue Sklaven im Innern Afrika's zu kaufen und an die Küste zu bringen.” Walter Sauer, "Schwarz-Gelb in Afrika: Habsburgermonarchie und koloniale Frage," in $k . u$. k. kolonial: Habsburgermonarchie und europäische Herrschaft in Afrika, ed. Walter Sauer, 2nd ed. (Vienna: Böhlau, 2007), 43. On Schreiner, whose criticism contributed to ending this form of human trafficking while at the same time making not endearing him to the decision-makers at the imperial foreign ministry in Vienna, see Beate Marakovits, "Die Verbindungen zwischen Österreich (-Ungarn) und Ägypten unter der Ära des Generalkonsuls Gustav Franz Freiherr von Schreiner 1858-1873” (diploma thesis: University of Vienna, 2005).

90 "Lokaler Tradition zufolge war es dessen Aufgabe, bei Tisch die Gäste zu bedienen, und bei den Ausfahrten seines Gebieters mit der Kutsche in einer goldbestickten Uniform, einen roten Fez auf dem Kopf, mit gekreuzten Armen hinter dem kutschierenden Herrn und dessen Frau zu sitzen. Medlum wurde als der 'Mohr von Hietzing' oder der 'Weidman-Muhrl' [derogatory colloquial variant of "Mohr" = Blackamoor] populär." Sulzbacher, "Beten - dienen - unterhalten," 103.

91 Markova and Sauer, "Waldhornblasender Gärtner," 95-110. 
"When a maidservant of the house, standing behind a window, called out to him: 'Musa, you are a black monkey!', he struck the windowpane into her face with his fist with the words: 'I am a human!' . . . As bad as the consequences were, I could not be cross with the boy over this; it was the deeply offended self-confidence, challenged and insulted every day, often in the most cruel manner, by idle, curious, and malicious people, that welled up in him."92

Reviewing the results of this study in the light of the question posed in the introduction, we find the following overall picture: The changes in the political and legal framework conditions due to the abolition of slavery and the slave trade complicated the mechanisms for procuring "exotic" servants in that the "obtainment" of these individuals - in general by purchasing them on slave markets - now had to occur outside of the European zones of influence or under circumvention of European abolition laws. In effect, this meant that the place of the former slave trader was assumed by the tourist. This was not necessarily accompanied by a development towards "free" labor, however; although the affected persons - most of them children - were considered free according to the Austrian Allgemeines Bürgerliches Gesetzbuch (General Civil Code) proclaimed in 1811, their latitude in everyday life remained extremely limited for a number of reasons (age, foreignness, servant status, lack of education and qualifications). Nevertheless, it must be stated clearly that this latitude increased over the course of time as a result of abolition and societal changes. We thus find individual persons with overseas origins who were able to transition into a self-determined existence, who practiced a profession (in some cases even very successfully) and even started families - especially when they received prominent support, like Johann Baptist Somoß or Angelo Soliman. But even in these rare cases, the lack of a welfare state and political participation - a situation that would only be remedied (for citizens) in the twentieth century with universal franchise - exacerbated their difficulties considerably. Finally, the increasing racial discrimination of members of the Black diaspora brought with it new limitations to their emancipation. While legally free, they saw themselves confronted with the social experience of an attributed otherness that largely prevented them from enjoying the benefits of this freedom.

92 "Einer Magd im Hause, die ihm, hinter einem Fenster stehend, zurief: 'Musa, Du bist ein schwarzer Affe!' schlug er mit der Faust die Scheiben in’s Gesicht, mit den Worten: 'Ich bin ein Mensch!' . . . Ich konnte, so entsetzlich die Folgen waren, dem Knaben darum nicht zürnen, es war das tief beleidigte Selbstbewußtsein, das aus ihm hervorbrach, das jeden Tag von Müssiggängern, Neugierigen, Boshaften oft in gemeinster Weise herausgefordert und beleidigt wurde.” Frankl, Nach Jerusalem!, 3:220. 


\section{References}

\section{Printed Sources}

August, Wilhelm. "Wien vor einem halben Jahrhundert. Fortsetzung." Der österreichische Zuschauer, August 30, 1839.

Frankl, Ludwig August. Nach Jerusalem! Vol. 3. Vienna [no publisher specified]: 1858.

Laimbeckhoven, Gottfried von. Neue Umständliche Reiß-Beschreibung. Von Wienn nach China abgeschickten Missionarii. Darinnen dessen ungemein beschwär- und gefährliche Schiffahrt von Genua bis Macao mit beygemengten vielen gar Lehr-reichen Astronomisch- und Geographischen Anmerckungen etc. Vienna: Prasser, 1740.

Prokesch-Osten Anton, ed. Aus dem Nachlasse des Grafen Prokesch-Osten, Briefwechsel mit Herrn von Gentz und Fürsten Metternich I. Vienna: Gerold, 1881.

Wiener Kirchenzeitung, October 21, 1856.

Zgodnja Danica, April 3, 1856.

\section{Literature}

Bertsch, Daniel. Anton Prokesch von Osten (1795 - 1876): Ein Diplomat Österreichs in Athen und an der Hohen Pforte. Beiträge zur Wahrnehmung des Orients im Europa des 19. Jahrhunderts. Munich: Oldenbourg, 2005.

Blom, Philipp, and Wolfgang Kos, eds. Angelo Soliman: Ein Afrikaner in Wien. Vienna: Wien Museum, 2011.

Bono, Salvatore. Piraten und Korsaren im Mittelmeer: Seekrieg, Handel und Sklaverei vom 16. bis 19. Jahrhundert. Stuttgart: Klett-Cotta, 2009.

Bono, Salvatore. Schiavi: Una storia mediterranea XVI-XIX secolo. Bologna: II mulino, 2016.

Conte Corti, Egon Caesar. Vom Kind zum Kaiser. Graz: Pustet, 1950.

Daget, S. "The Abolition of the Slave Trade." In: Africa in the Nineteenth Century until the 1880s, edited by J. F. Ade Ajayi, 64-89. Paris: UNESCO, 2000 (Reprint).

Debrunner, Hans Werner. Presence and Prestige: A History of Africans in Europe before 1918. Basel, Basler Afrika-Bibliographien, 1979.

Felder, Cajetan. Erinnerungen eines Wiener Bürgermeisters. Vienna: Forumverlag, 1964.

Frank, Alison. "The Children of the Desert and the Laws of the Sea: Austria, Great Britain, the Ottoman Empire, and the Mediterranean Slave Trade in the Nineteenth Century." American Historical Review 117, no. 2 (April 2012): 410-444.

Görlich, Ernst Joseph. "Eine äthiopische Fürstentochter in Wien.” Wiener Geschichtsblätter 28 (1973): 84-86.

Graff, Theodor. "Frà Johann Joseph von Herberstein, Generalkapitän der Malteserflotte: Sein Einsatz gegen die Türken in der Levante und in Dalmatien in den Jahren 1686 und 1687." Zeitschrift des Historischen Vereins für Steiermark 89/90 (1988-90): 85-127.

Habermas, Jürgen. Strukturwandel der Öffentlichkeit: Untersuchungen zu einer Kategorie der bürgerlichen Gesellschaft. 4th ed. Neuwied-Berlin: Luchterhand, 1969.

Harrer, Friedrich, and Patrick Warto. "Das ABGB und die Sklaverei." In: 200 Jahre ABGB: Die Bedeutung der Kodifikation für andere Staaten und andere Rechtskulturen, edited by Michael Geistlinger et al., 283-290. Vienna: Manz, 2011. 
Hecht, Louise. Ludwig August Frankl (1810-1894): Eine jüdische Biographie zwischen Okzident und Orient. Cologne: Böhlau, 2016.

Kametler, Josef. "Zeitzeugenberichte. Auszug aus dem Stadtbuch von Jennersdorf." In 800 Jahre Weichselbaum 1187-1987: Festschrift Wappenverleihung und Gemeindehauseinweihung am 5. Juli 1987, 63-71. Weichselbaum: Gemeinde Weichselbaum, 1987.

Küppers-Braun, Ute. "P. Nicolò Oliveiri und der (Los-)Kauf afrikanischer Sklavenkinder." Schweizerische Zeitschrift für Religions- und Kulturgeschichte 105 (2011): 141-166.

Kurz, Marlene., Walter Scheutz, Karl Vocelka, and Thomas Winkelbauer, eds. Das Osmanische Reich und die Habsburgermonarchie: Akten des Internationalen Kongresses zum 150-jährigen Bestehen des Instituts für Österreichische Geschichtsforschung. Vienna: Böhlau, 2005.

Marakovits, Beate. "Die Verbindungen zwischen Österreich(-Ungarn) und Ägypten unter der Ära des Generalkonsuls Gustav Franz Freiherr von Schreiner 1858-1873.” Diploma thesis: University of Vienna, 2005.

Markova, Ina, and Walter Sauer. "Waldhornblasender Gärtner: Ein schwarzer Brasilianer im vormärzlichen Österreich. Oder: Vom Wilden zum Weltbürger und wieder zurück?” Wiener Geschichtsblätter 66, no. 2 (2011): 95-110.

Meisterle, Stefan. “Von Coblon bis Delagoa: Die kolonialen Aktivitäten der Habsburgermonarchie in Ostindien." PhD diss., University of Vienna, 2014, http://othes.univie.ac.at/35012/.

Montjoye, Irene. Maria Theresias Türkenkind: Die abenteuerliche Lebensgeschichte der Anna Maria Königin. Vienna: Czernin, 2000.

Oberacker, Carlos H. Leopoldine: Habsburgs Kaiserin von Brasilien. Vienna: Amalthea, 1988.

Otruba, Gustav. "Österreichische Jesuitenpatres des 17. und 18. Jahrhunderts in der Weltmission und als Erforscher der Erde." Österreich in Geschichte und Literatur 5, no. 1 (1961): 29-39.

Quakatz, Manja. “'Gebürtig aus der Türckey': Zu Konversion und Zwangstaufe osmanischer Muslime im Alten Reich um 1700." In Europa und die Türkei im 18. Jahrhundert / Europe and Turkey in the 18th Century, edited by Barbara Schmidt-Haberkamp, 417-430. Bonn: V\&R unipress, 2011.

Rabanser, Hansjörg. “'Mit einem krummen Pferd und einem einhändigen Gutscher.' Die VenedigReise der Familie Vogl im Jahr 1835." Wissenschaftliches Jahrbuch der Tiroler Landesmuseen 5 (2012): 412-443.

Reimann, Sarah. Die Entstehung des wissenschaftlichen Rassismus im 18. Jahrhundert. Stuttgart: Steiner, 2017.

Rohrbacher, Peter. "Franz Xaver Logwit-lo-Ladu (1848-1866): Seine Bedeutung als afrikanische Gewährsperson in der Frühphase der österreichischen Afrikanistik." In Afrikanische Deutschland-Studien und deutsche Afrikanistik - ein Spiegelbild, edited by Michel Espagne, Pascale Rabault-Feuerhahn, and David Simo, 49-72. Würzburg: Königshausen \& Neumann, 2014.

Sauer, Walter. “'Mohrenmädchen' in Bludenz, 1855-1858: Ein Beitrag zur Geschichte der afrikanischen Diaspora in Österreich." Montfort: Vierteljahresschrift für Geschichte und Gegenwart Vorarlbergs 56, no. 4 (2004): 293-300.

Sauer, Walter. "Schwarz-Gelb in Afrika: Habsburgermonarchie und koloniale Frage." In: K. u. $k$. kolonial: Habsburgermonarchie und europäische Herrschaft in Afrika, edited by Walter Sauer, 17-78. 2nd ed., Vienna: Böhlau, 2007.

Sauer, Walter, ed. Von Soliman zu Omofuma: Geschichte der afrikanischen Diaspora in Österreich 17. bis 20. Jahrhundert. Innsbruck: Studienverlag, 2007.

Sauer, Walter, and Andrea Wiesböck. "Sklaven, Freie, Fremde: Wiener 'Mohren' des 17. und 18. Jahrhunderts." In Von Soliman zu Omofuma: Geschichte der afrikanischen Diaspora in Österreich 17. bis 20. Jahrhundert, edited by Walter Sauer, 23-56. Innsbruck: Studienverlag, 2007. 
Sauer, Walter. "Angelo Soliman: Mythos und Wirklichkeit." In Von Soliman zu Omofuma: Geschichte der afrikanischen Diaspora in Österreich 17. bis 20. Jahrhundert, edited by Walter Sauer, 59-96. Innsbruck: Studienverlag, 2007.

Sauer, Walter. "Egyptian Migration to the Habsburg Empire in the 19th Century." In Egypt and Austria III: The Danube Monarchy and the Orient. Proceedings of the Prague Symposium 2006, edited by Johanna Holaubek, Hana Navrátilová, and Wolf B. Oerter, 207-218. Prague: Set Out, 2007.

Sauer, Walter. "Habsburg Colonial: Austria-Hungary's Role in European Overseas Expansion Reconsidered." In Colonial Austria: Austria and the Overseas. Austrian Studies 20, edited by Florian Krobb (2012): 5-23.

Sauer, Walter. "'Und man siehet die im Lichte, die im Dunkeln sieht man nicht.' Neue Beiträge zu einer Kollektivbiographie von Afrikanern und Afrikanerinnen im frühneuzeitlichen Österreich.” Wissenschaftliches Jahrbuch der Tiroler Landesmuseen 9 (2016): 232-247.

Sauer, Walter. "Exotische Schaustellungen im Wiener Vormärz: Zwischen Voyeurismus und früher Rassentheorie." Mitteilungen des Instituts für österreichische Geschichtsforschung 124, no. 2 (2016), 391-417.

Schlag, Gerald. ““. . . Die Anstalt des Fürsten Esterházy jedoch übertraf alle die übrigen.’ Fürst Nikolaus I. Esterházy als kurböhmischer Wahlbotschafter bei der Wahl und Krönung Josephs II. zum römischen König 1764." In Archivar und Bibliothekar: Bausteine zur Landeskunde des burgenländischen-westungarischen Raumes. Festschrift für Johann Seedoch zum 60. Geburtstag, edited by Felix Tobler and Norbert Frank, 437-455. Eisenstadt: Amt der Burgenländischen Landesregierung, 1999.

Schmidt-Linsenhoff, Viktoria. “Mit Mohrenpage.” In Ästhetik der Differenz: Postkoloniale Perspektiven vom 16. bis 21. Jahrhundert. 15 Fallstudien, edited by Viktoria SchmidtLinsenhoff, 249-266. Marburg: Jonas, 2014.

Schmutzer, Kurt. Der Liebe zur Naturgeschichte halber: Johann Natterers Reisen in Brasilien 1817-1836. Vienna: Verlag der Österreichischen Akademie der Wissenschaften, 2011.

Sulzbacher, Christine. "Beten - dienen - unterhalten. Zur Funktionalisierung von Afrikanern und Afrikanerinnen im 19. Jahrhundert in Österreich." In Von Soliman zu Omofuma: Geschichte der afrikanischen Diaspora in Österreich 17. bis 20. Jahrhundert, edited by Walter Sauer, 99-128. Innsbruck: Studienverlag, 2007.

Teply, Karl. "Vom Los osmanischer Gefangener aus dem Großen Türkenkrieg 1683-1699.” Süd-OstForschungen 32 (1973): 33-72.

Watzka-Pauli, Elisabeth. Triumph der Barmherzigkeit: Die Befreiung christlicher Gefangener aus muslimisch dominierten Ländern durch den österreichischen Trinitarierorden 1690-1783. Göttingen: V\&R unipress, 2016.

Wheatcroft, Andrew. The Enemy at the Gate. Habsburgs, Ottomans and the Battle for Europe. London: Pimlico, 2009.

Wolfram, Caroline. "Außereuropäische Einflüsse auf die bürgerliche Öffentlichkeit des frühen Vormärz und den österreichischen Frühliberalismus." Master's thesis, University of Vienna, 2018, http://othes.univie.ac.at/51022/.

Zunker, Maria Magdalena. "Drei arme Mohrenkinder in der Benediktinerinnenabtei St. Walburg, Eichstätt: Eine Spurensuche." Studien und Mitteilungen zur Geschichte des Benediktinerordens und seiner Zweige 114 (2003): 481-532. 
Annika Bärwald

\section{Black Hamburg: People of Asian and African Descent Navigating a Late Eighteenth- and Early Nineteenth-Century Job Market}

In 1821, an advertisement appeared in a Hamburg newspaper stating that "James Thomson, the Negro baptized here some years ago, born in Congo, twenty-six years of age," was "currently seeking a new position." The text asserted that Thomson had since "served in Harburg and Cöthen" - the former a town neighboring Hamburg, the latter the seat of a far-removed principality near Leipzig - and could "provide very laudable attestations from both masters." He was a capable man who knew "how to handle horses, and he dr[ove] reliably." Upon his return to Hamburg, Thomson had reconnected with people he had known for at least four years: Georg Bernhard Grautoff, the pastor of the local Church of St. Catherine who had baptized him in 1817 and now provided him with a recommendation, and Anna Margaretha Kasang, Thomson's godmother and an innkeeper with whom he stayed during his search for a job. ${ }^{2} \mathrm{Al}-$ though the advertisement consisted of only a few lines, it made clear that Thomson knew his way around and was acquainted with people he could rely on.

Thomson was not the only person of African descent in search of a paying occupation. Within five decades, from 1788 to 1839, at least twenty-one other people of non-European descent sought employment through Hamburg newspapers in similar

\footnotetext{
1 James Thomson, "Personen, welche ihre Dienste anbieten," Privilegirte Wöchentliche gemeinnützige Nachrichten von und für Hamburg, May 17, 1821, 117. In the following, advertisements will be referred to by newspaper acronym [WN for Wöchentliche Nachrichten, BH for Börsen-Halle, ACN for Addreß-Comtoir-Nachrichten], date, and page number only. All translations are my own.

2 See WN, May 17, 1821, 6; Hamburg State Archive, 512-4 St. Katharinen Kirche, A XVII a 19 II Taufbuch 1816-1818, 273.
}

\footnotetext{
Notes: I would like to thank my advisors and colleagues in Bremen as well as the attendants of the Global History Student Conference Istanbul 2018 and the History beyond Boundaries workshop organized by IEG Mainz in conjunction with Oxford University in 2019 for their helpful comments and suggestions on earlier versions of this text. Dan Durcan and Thom Lloyd provided invaluable help in copy editing the final version. All remaining mistakes are my own. This project is funded by the European Research Council (ERC) under the Horizon 2020 Research and Innovation Program of the European Union (Grant No. 641110 "The Holy Roman Empire of the German Nation and its Slaves"). However, this text exclusively reflects the author's views. The ERC is neither responsible for the content nor for its use.
} 